\title{
Comparative evaluation of the anti-Hepatitis B virus activity of Centella asiatica and Camellia sinensis (green tea)
}

\author{
S Thanigaivel ${ }^{1}$, H Durgadevi $^{1}$, J Balasubramaniam² ${ }^{2}$ V Mythily², M Elanchezhiyan ${ }^{*}$ \\ From 2nd International Science Symposium on HIV and Infectious Diseases (HIV SCIENCE 2014) \\ Chennai, India. 30 January - 1 February 2014
}

\section{Background}

Chronic Hepatitis B virus (HBV) infection is a major health problem and available anti-HBV drugs are known to cause side effects in addition to increased incidence of drug resistance. In the current study anti-HBV properties of Centella asiatica and Camellia sinensis was evaluated.

\section{Methods}

For the assay, equal volume of HBV virus was mixed with extract of $C$. asiatica or $C$. sinensis and incubated at $37^{\circ} \mathrm{C}$ for 5 days. The supernatant was assayed for the presence of bound/unbound HBsAg using ELISA. A dose response analysis was done for each extract and cytotoxicity of the each extract was measured by MTT assay.

\section{Results}

Dose response anti HBV revealed that methanolic extract $C$. asiatica indicated that $2.5 \mathrm{mg} / \mathrm{mL}$ concentrations was inhibitory to $0.75 \mathrm{pg} / \mathrm{mL}$ of $\mathrm{HBV}$. Aqueous and methanolic extract of $C$. sinensis indicated that $0.5 \mathrm{mg} / \mathrm{mL}$ and 0.25 concentrations inhibited HBV, respectively. Interestingly, EGCG indicated $1.5 \mathrm{pg} / \mathrm{mL}$ HBV was inhibited by $25 \mu \mathrm{g} / \mathrm{mL}$. These concentrations were well tolerated by HepG2 cells and the non toxic concentration was up to $800 \mu \mathrm{g} / \mathrm{mL}$.

\section{Conclusion}

The study showed that EGCG outperformed other extracts and had anti-HBV activity with minimal

\footnotetext{
* Correspondence: emanickan@yahoo.com

'Department of Microbiology, Dr. ALM PG IBMS, University of Madras,

Chennai, India

Full list of author information is available at the end of the article
}

concentration $(25 \mu \mathrm{g} / \mathrm{mL})$. This is followed by extracts of $C$. sisensis which exhibited medium anti HBV activity. Poorest anti-HBV activity was noticed with $C$. asiatica i.e. $2.5 \mathrm{mg}$. None of the extracts had cytotoxicity. From this study we could conclude that $C$. sinensis extracts are better in inhibiting HBV.

\section{Authors' details \\ ${ }^{1}$ Department of Microbiology, Dr. ALM PG IBMS, University of Madras, Chennai, India. 'Blood Bank, Voluntary Health Services (VHS), Taramani,} Chennai, India.

Published: 27 May 2014

doi:10.1186/1471-2334-14-S3-P21

Cite this article as: Thanigaivel et al: Comparative evaluation of the anti-Hepatitis B virus activity of Centella asiatica and Camellia sinensis (green tea). BMC Infectious Diseases 2014 14(Suppl 3):P21.
Submit your next manuscript to BioMed Central and take full advantage of:

- Convenient online submission

- Thorough peer review

- No space constraints or color figure charges

- Immediate publication on acceptance

- Inclusion in PubMed, CAS, Scopus and Google Scholar

- Research which is freely available for redistribution

Submit your manuscript at www.biomedcentral.com/submit
( Biomed Central 